\title{
PEMILIHAN TEKNOLOGI PROSES GEOTHERMAL SECARA TEKNIS PADA PEMBANGKIT LISTRIK TENAGA PANAS BUMI DI INDONESIA
}

\author{
Daril Ridho Zuchrillah ${ }^{1}$, Renanto Handogo ${ }^{2}$ Juwari $^{3}$ \\ Teknik Kimia, Fakultas Teknologi Industri, ITATS ${ }^{1}$ \\ Teknik Kimia, Fakultas Teknologi Industri, ITS Surabaya ${ }^{2,3}$ \\ email ${ }^{1}$ : darilridho@itats.ac.id
}

\begin{abstract}
Currently, geothermal power plants produce base load electricity is cheaper, reliable and green. However, the efficiency of conversion contained in a geothermal power plant is smaller than other fossil power plants. PT. Geo Dipa Energi unit Dieng, Central Java is one of the company's power plants in Indonesia that utilize geothermal energy in the form of steam as a prime mover with flash steam technology. Selection of flash steam process technology has been developed with the model mathematical approach based on the laws of thermodynamics using software Engineering Equation Solver (EES). In this study we can conclude that the physical quality of the steam generated from the production wells and has a temperature of $306{ }^{\circ} \mathrm{C}$ and enthalpy value of $1379.7 \mathrm{~kJ} / \mathrm{kg}$, operating conditions separator used software EES is in the temperature $1000{ }^{\circ} \mathrm{C}$ and pressure in $179.9 \mathrm{kPa}$ with generate electric power of 13.929,63 $\mathrm{kWe}$ with the magnitude of the efficiency of $23,41 \%$. Then the simulation modeling has been carried out with a combination of single flash steam with binary cycle. This combination of technologies single flash steam and binary cycle power it produces at 18.456,24 $\mathrm{kW}$ with overall plant efficiency of $31,02 \%$. It has the greatest efficiency that is referred to as selection of appropriate technology to process geothermal power plant in PT. Geo Dipa Energi unit Dieng, Central Java. While the combination of single flash technology with dual binary cycle power it produces at 18.329,768 kW with overall plant efficiency of 30,81\%.
\end{abstract}

Keyword : Geothermal, Power Plant, Binary Cycle, Flash Steam, Efficiency

\section{ABSTRAK}

Saat ini, geothermal power plant memproduksi beban dasar listrik yang lebih murah, handal dan ramah lingkungan. Namun efisiensi konversi yang terdapat pada pembangkit listrik tenaga panas bumi sangatlah kecil daripada pembangkit listrik tenaga fosil lainnya. PT. Geo Dipa Energi unit Dieng, Jawa Tengah merupakan salah satu perusahan pembangkit listrik di Indonesia yang memanfaatkan energi panas bumi berupa steam sebagai penggerak utama dengan teknologi flash steam. Pemilihan teknologi proses flash steam telah dikembangkan dengan model pendekatan matematis berdasarkan hukum termodinamika menggunakan software Engineering Equation Solver (EES). Pada penelitian ini dapat disimpulkan bahwa kualitas fisik steam yang dihasilkan dari sumur produksi dalam suhu $306{ }^{\circ} \mathrm{C}$ dan mempunyai nilai entalpi sebesar 1379,7 kJ/kg, Kondisi operasi separator yang digunakan perangkat lunak EES berada di suhu 179,9 ${ }^{\circ} \mathrm{C}$ dan tekanan $1000 \mathrm{kPa}$ dengan menghasilkan daya listrik sebesar 13.929,63 kWe dengan besarnya efisiensi 23,41 \%. Telah dikembangkan simulasi pemodelan dengan kombinasi antara single flash steam dengan binary cycle. Kombinasi teknologi single flash steam dan binary cycle ini menghasilkan daya sebesar 18.456,24 kW dengan efisiensi overall plant sebesar 31,02 \%. Hal tersebut memiliki efisiensi terbesar sehingga dirujuk sebagai pilihan teknologi proses geothermal yang tepat untuk PLTP PT. Geo Dipa Energi unit Dieng, Jawa Tengah. Sedangkan teknologi kombinasi single flash dengan dual binary cycle ini menghasilkan daya sebesar 18.329,768 kW dengan efisiensi overall plant sebesar 30,81\%.

Kata kunci : Geothermal, Power Plant, Binary Cycle, Flash Steam, Efisiensi

\section{PENDAHULUAN}

Saat ini, pembangkit listrik tenaga panas bumi berkembang sangat pesat. Prediksi jangka pendek mengindikasi bahwa akan terpasang berbagai plant dengan kapasitas 18.500 Megawatt pada tahun 2015. Ini menunjukkan bahwa sebuah peningkatan sebesar 73\% dari tahun 2010 [1]. Potensi energi panas bumi di Indonesia dipastikan sangat besar dengan kapasitas energi listrik yang bisa dihasilkan mencapai 29.000 Megawatt atau setara $40 \%$ potensi panas bumi di dunia. Tersebarnya lokasi panas bumi juga akan mempengaruhi karakteristik pembangkit listrik tenaga 
panas bumi (PLTP). Setiap lahan yang berbeda mempunyai tingkat temperatur maupun tekanan uap yang berbeda pula, sehingga terbagi menjadi 3 tipe pembangkit, yaiut Dry Steam, Flash Steam dan Binary Cycle. Tipe pembangkit ini akan mempengaruhi sistem proses atau proses flow sebuah pembangkit panas bumi [2].

Pembangkit listrik tenaga panas bumi mempunyai efisiensi yang relatif lebih rendah daripada pembangkit listrik tenaga thermal yang lain seperti batubara, gas alam, minya dan nuklir. PLTP umumnya hanya 10\% energi dari geo fluida yang diproduksi untuk dijadikan sebagai daya listrik. Ada penelitian yang menyatakan bahwa konversi daya listrik yang dihasilkan yaitu sebesar 10-17\%. Sementara penelitian lainnya menunjukkan bahwa efisiensi $18 \%$ untuk teknologi sistem single flash steam dengan tekanan masuknya sebesar 6,5 bar. Bagaimanapun setiap PLTP mempunyai efisiensi konversi masing-masing yang tergantung oleh faktor yang mempengaruhinya. Faktor yang mempengaruhi diantaranya adanya kandungan non-condensable gas (NCG), beban parasit yang dibutuhkan, panas hilang, efisiensi turbin dan efisiensi generator [3].

Pada penelitian ini, tahapan menganalisa daya listrik sebuah pembangkit listrik tenaga panas bumi perlu dilakukan sebagai langkah awal untuk mencegah timbulnya dampak negatif yang lebih besar. Perlakuannya adalah penerapan analisa energi dan eksergi dengan menerapkan hukum termodinamika. Hasil dari analisa nantinya akan digunakan untuk pemilihan teknologi proses yang tepat dengan menghasilkan daya listrik maksimum. Salah satunya adalah mengoptimasi kondisi operasi flasher pada modifikasi double flash steam untuk mendapatkan daya listrik yang diproduksi lebih besar. Lalu dilakukan modifikasi teknologi double flash steam untuk menfaatkan brine hasil keluaran separator bertekanan tinggi pada kondisi operasi yang sama. Selain itu, disimulasikan dalam teknologi basic binary, kombinasi antara single flash dengan binary dan kombinasi single flash dengan dual binary.

\section{TINJAUAN PUSTAKA}

Teknologi proses pembangkit listrik tenaga panas bumi yang paling banyak diterapkan di dunia termasuk di Indonesia adalah teknologi flash steam. Pembangkit jenis memanfaatkan geofluid dengan kisaran suhu $180-300^{\circ} \mathrm{C}$. Geofluida tersebut akan dipisahkan ke tangki yang suhu dan tekanannya lebih rendah untuk kemudian dengan cepat membentuk 2 fasa yaitu uap dan cair. Uap ini akan menggerakkan turbin yang selanjutnya menggerakkan generator untuk menghasilkan daya listrik. Faktor kapasitasnya dapat mencapai 93\% dan modalnya per kWe mencapai 1.250 hingga 1.300 dolar amerika [4].

Penelitian pada tahun 2016, simulasi telah dilakukan pada teknologi single flash steam dengan kondisi operasi separator yaitu tekanan operasi sebesar $1000 \mathrm{kPa}$ dengan mendapatkan daya listrik terbesar yaitu sebesar 23.030,28 kWe dengan besarnya efisiensi hukum kedua termodinamika adalah $38,71 \%$. Dalam teknologi proses double flash steam ini dibutuhkan modifikasi dari single flash steam dengan penambahan separator bertekanan rendah (flasher). Pada teknologi yang telah ada, brine mengalir dari separator bertekanan tinggi ke flasher. Dalam perancangannya, brine akan mengalir menuju flasher untuk diekspansi kali keduanya. Steam akan menuju ke turbin bertekanan rendah dan steam keluarannya menuju kondensor. Optimisasi dilakukan pada kondisi operasi seperator bertekanan rendah (flasher) menunjukkan bahwa pada tekanan $140 \mathrm{kPa}$ dengan suhu $109,3^{\circ} \mathrm{C}$ mendapatkan daya listrik terbesar yaitu sebesar 27.396,39 $\mathrm{kWe}$ dengan besarnya efisiensi $46,05 \%$. Hal tersebut dilakukan dengan asumsi efisiensi generator yang digunakan sebesar yaitu $91 \%$ [5]. 


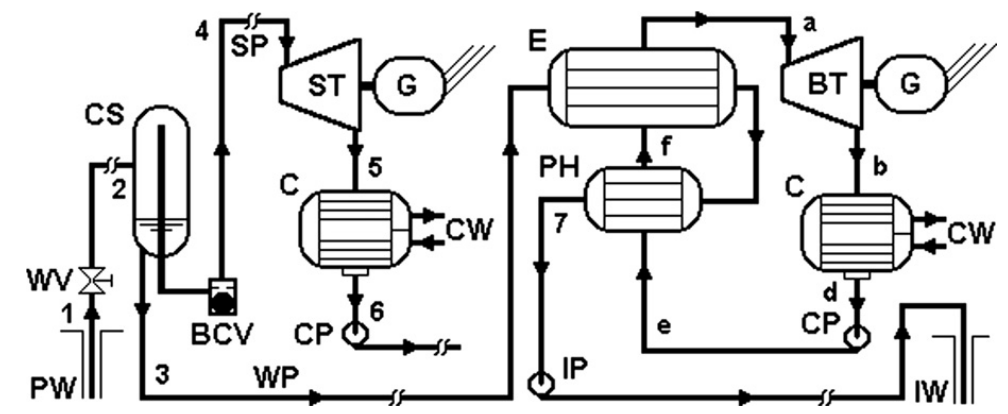

Gambar 1. Model PLTP dengan teknologi kombinasi Single-Flash dan Basic Binary Plant

Sebuah alterantif untuk memanfaatkan hasil pemisahan brine dari separator pada flash steam plants yaitu dengan menambahkan sistem binary cycle. Kombinasi flash-binary telah beroperasi pada beberapa pembangkit listrik tenaga panas bumi di dunia. Daya listrik yang dihasilkan akan lebih meningkatkan dengan adanya penambahan unit binary antara separator dengan sumur injeksi [6]. Alternatif beberapa teknologi ini diharapkan dapat meningkatkan efisiensi konversi energi geothermal menjadi suatu tenaga pembangkit listrik.

Analisa eksergi bisa diterapkan di banyak bidang, terkhusus pada industri yang bekerja dengan pemanfatan energi termal. Analisis eksergi terbukti sangat bermanfaat dalam menilai kinerja suatu sistem [7]. Bentuk eksergi yang digunakan yaitu eksergi fisik, juga dikenal sebagai thermo mechanical exergy adalah kerja yang diperolah dari kondisi awal $(\mathrm{T}, \mathrm{P})$ menuju kondisi lingkungan $\left(\mathrm{T}_{0}, \mathrm{P}_{0}\right)$. Eksergi fisik spesifik dapat ditulis sebagai berikut :

$\dot{E}_{t}=\dot{m}_{t}\left[\left(h_{i}-h_{0}\right)-T_{0}\left(s_{i}-s_{0}\right)\right]$

Dimana $\dot{E}_{t}$ adalah eksergi, $\dot{m}_{t}$ adalah mass flow rate, $h$ adalah entalpi, $h_{0}$ adalah entalpi pada suhu dan tekanan ambient, $t_{0}$ adalah suhu ambien, $s$ adalah entropi kondisi operasi dan $s_{0}$ adalah entropi pada suhu dan tekanan ambien [8].

Efisiensi didefinisikan sebagai perbandingan antara eksergi masuk sebagai eksergi yang digunakan dengan eksergi keluar sebagai eksergi yang termanfaatkan. Efisiensi eksergi dapat ditulis.

$\eta_{\text {ex }}=\frac{\dot{E}_{\text {out }}}{\dot{E}_{\text {in }}}$

Dapat juga ditulis harga efisiensi eksergi sebagai efisiensi hukum kedua termodinamika sebagai berikut

$\eta_{I I}=\frac{\dot{W}_{n e t}}{\dot{E}_{\text {in }}}$

Dimana $\eta_{I I}$ adalah efisiensi eksergetik, $\dot{W}_{\text {net }}$ adalah daya listrik netto dan $\dot{E}_{\text {in }}$ adalah eksergi total yang masuk ke plant.

\section{METODE PENELITIAN}

Penelitian ini telah melakukan pengumpulan data Pembangkit Listrik Tenaga Panas Bumi di PT. Geo Dipa Energi unit Dieng dari refrensi data jurnal. Dari tempat tersebut mengambil data kapasitas reservoir geothermal, kondisi operasi dan hasil data produksi. Setalah pengumpulan data yang dibutuhkan, telah melakukan pemodelan teknologi geotermal sistem flash steam dengan menggunakan data-data refrensi di pembangkit listrik tersebut. Didapatkan data seperti suhu Wellhead sebesar $306^{\circ} \mathrm{C}$, laju alir massa $500.040 \mathrm{~kg} / \mathrm{jam}$ dan entalpi reservoir sebesar $1.379,7$ $\mathrm{kJ} / \mathrm{kg}$. Kondisi operasi separator dan turbin masing-masing bertekanan $1000 \mathrm{kPa}$ dan $7 \mathrm{kPa}$ [9].

Dalam melakukan simulasi model pembangkit listrik tenaga panas bumi teknologi binary cycle ini menggunakan perangkat lunak Aspen HYSIS 7.3. Data untuk teknologi single flash steam menggunakan hasil optimasi yang telah dilakukan, sedangkan untuk teknologi binary cycle 
menggunakan beberapa asumsi yang dilakukan sebagai berikut: (1) Jenis Fluida kerja dalam binary cycle adalah isopentana, $\mathrm{i}-\mathrm{C}_{5} \mathrm{H}_{12}$, sedangkan fluida panasnya berupa air $\left(\mathrm{H}_{2} \mathrm{O}\right)$. Hal selanjutnya adalah menentukan fluid packages yang digunakan pada simulasi sistem tersebut. Untuk hal ini, penulis menggunakan persamaan Peng-Robinson. (2) Kondisi operasi pada masing-masing preheater dan evaporator bertekanan $2000 \mathrm{kPa}$. (3) Suhu keluar dari kondensor adalah $46,85^{\circ} \mathrm{C}$. (4) Efisiensi turbin dan pompa yang digunakan masing - masing adalah $85 \%$ dan $75 \%$ dan (5) Pressure loss pada semua komponen diabaikan.

Setelah melakukan kombinasi dengan 1 loop binary cycle, maka langkah selanjutnya yaitu memanfaatkan kembali brine keluaran dari preheater pada loop pertama binary cycle untuk memanaskan fluida kerja dalam binary cycle selanjutnya. Kondisi operasi yang digunakan adalah tekanan dengan $686,9 \mathrm{kPa}$.

\section{HASIL DAN PEMBAHASAN}

Simulasi pemodelan dengan kombinasi antara single flash steam dengan binary cycle. Dalam melakukan simulasi model pembangkit listrik tenaga panas bumi teknologi binary cycle ini menggunakan perangkat lunak Aspen HYSIS 7.3. Data untuk teknologi single flash steam menggunakan data dengan kondisi operasi separator bertekanan $1000 \mathrm{kPa}$ dan suhu $179,9^{\circ} \mathrm{C}$. Sedangkan untuk teknologi binary cycle menggunakan beberapa asumsi yang dibuat sebelumnya menggunakan fluida kerja siklus berupa isopentana, $\mathrm{i}-\mathrm{C}_{5} \mathrm{H}_{12}$.

Pada gambar 2 menunjukkan dalam Aspen HYSIS telah dibuat skema PLTP dengan teknologi basic binary cycle dengan kondisi operasi masing-masing pada setiap arus. Geofluida masuk sebagai pemanas pada Evaporator (E-100) yang akan memanaskan isopentana sebagai working fluida menjadi vapor untuk diekspansi dalam turbin (K-100) dengan menghasilkan kerja. Dalam siklus ini memerlukan pompa (P-100) yang akan mengirimkan isopentane fasa cair dari cooler (E-101) menuju preheater (E-102) untuk dipanaskan kembali. Banyaknya massa isopentane sebagai working fluida sebanyak $410.000 \mathrm{~kg} / \mathrm{jam}(113,89 \mathrm{~kg} / \mathrm{s})$.

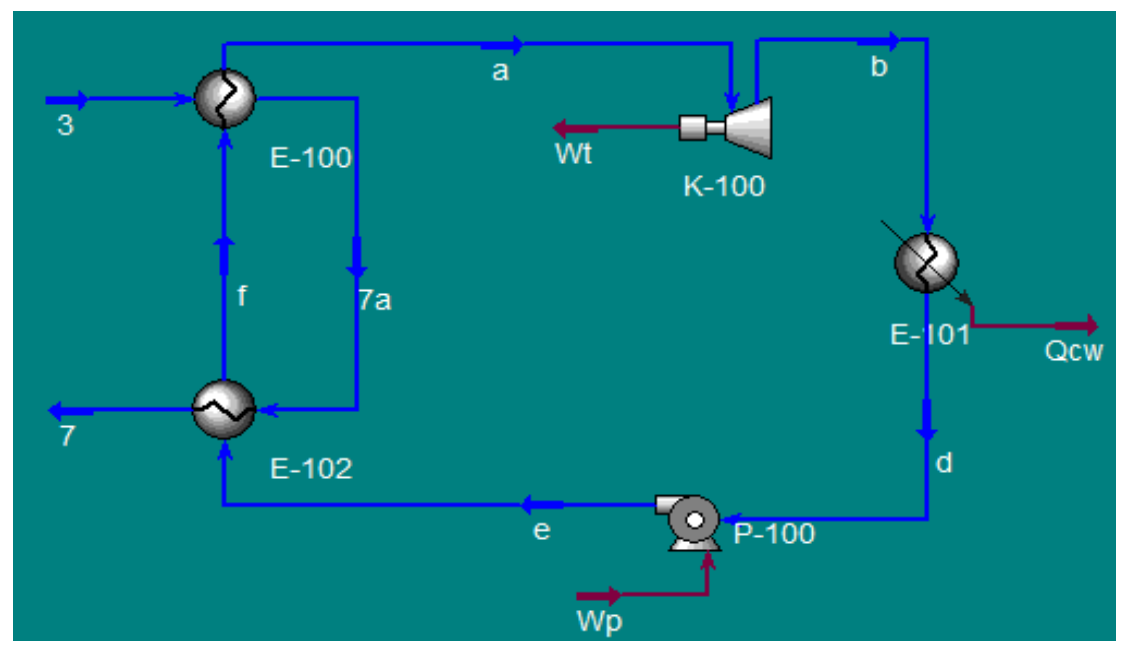

Gambar 2. Skema PLTP dengan teknologi Binary Cycle pada kombinasi Single Flash dan Binary cycle

Tabel 1. Hasil Simulasi PLTP teknologi Binary Cycle pada kombinasi Single Flash dan Binary cycle dengan Aspen HYSIS

\begin{tabular}{|c|c|c|c|}
\hline Arus & $\mathbf{P}(\mathbf{k P a})$ & $\mathbf{T}(\mathbf{K})$ & $\begin{array}{c}\text { Laju Massa } \\
(\mathbf{k g} / \mathbf{s})\end{array}$ \\
\hline 3 & 1000 & 453,15 & 340.920 \\
\hline
\end{tabular}




\begin{tabular}{|c|c|c|c|}
$7 \mathrm{a}$ & 1000 & 434,45 & 340.920 \\
\hline Arus & $\mathbf{P}(\mathbf{k P a})$ & $\mathbf{T}(\mathbf{K})$ & $\begin{array}{c}\text { Laju Massa } \\
(\mathbf{k g} / \mathbf{s})\end{array}$ \\
\hline 7 & 1000 & 322,33 & 340.920 \\
\hline $\mathrm{a}$ & 2000 & 427,55 & 410.000 \\
\hline $\mathrm{b}$ & 186,6 & 365,55 & 410.000 \\
\hline $\mathrm{d}$ & 186,6 & 320 & 410.000 \\
\hline $\mathrm{e}$ & 2000 & 321,27 & 410.000 \\
\hline $\mathrm{f}$ & 2000 & 427,55 & 410.000 \\
\hline
\end{tabular}

Pada tabel diatas didapatkan hasil simulasi turbin menghasilkan daya sebesr $8.695 \mathrm{~kW}$, sedangkan pompa membutuhkan daya sebesar $464,8 \mathrm{~kW}$. Oleh karena itu, sistem binary cycle ini menghasilkan daya listrik bersih sebesar $4.526,61 \mathrm{~kW}$ dengan efisiensi generator sebesar $55 \%$. Sehingga kombinasi teknologi single flash steam dan binary cycle ini menghasilkan daya sebesar 18.456,24 kW dengan efisiensi overall plant (hukum kedua termodinamika) sebesar 31,02\%. Sedangkan untuk efisiensi carnot cycle dan efisiensi thermal cycle untuk sistem binary cycle sendiri sebesar $25,15 \%$ dan 15,02 \%. Sedangkan efisiensi carnot cycle untuk sistem kombinasi single flash dan binary cycle sebesar 31,87\%, dengan suhu brine keluaran dari preheater sebesar $49,18{ }^{\circ} \mathrm{C}$. Hal tersebut menunjukkan terjadi peningkatan daya sebesar $32,49 \%$ dari single flash steam. Hal tersebut sesuai dengan literatur yang menunjukkan bahwa akan meningkatkan efisiensi lebih dari $20 \%$ [10].
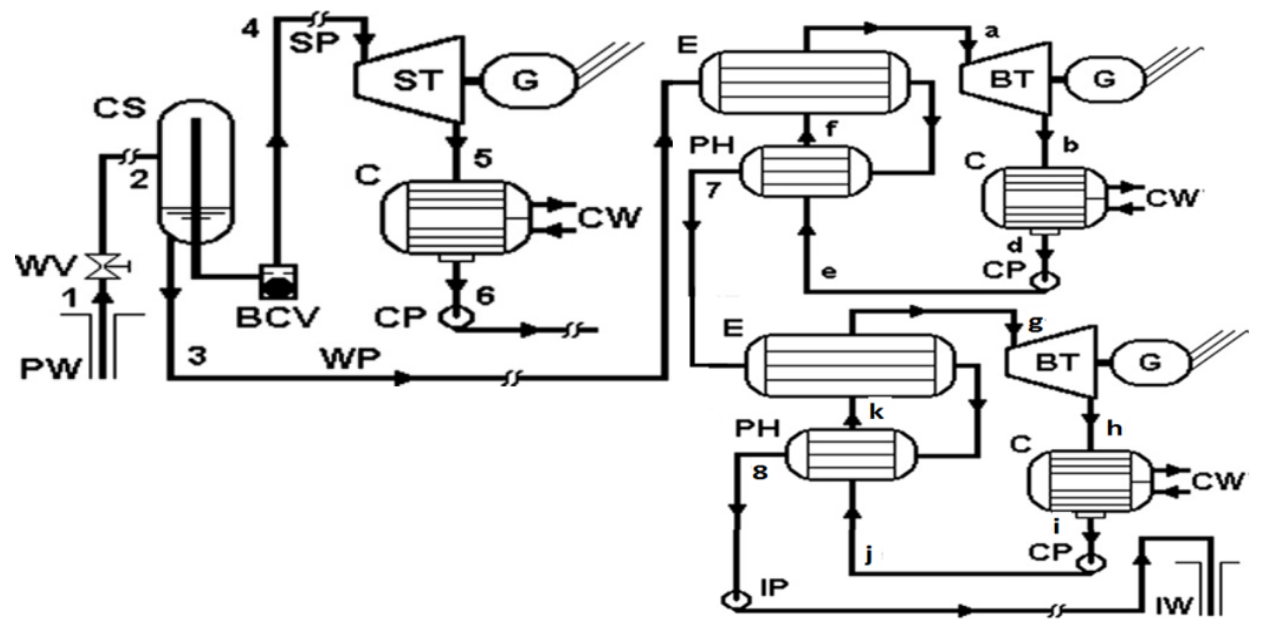

Gambar 3. Model PLTP dengan kombinasi teknologi Single Flash Steam dan Dual Binary Cycle

Langkah selanjutnya adalah telah melakukan simulasi kombinasi teknologi single flash dan dual binary cycle, dengan suhu brine yaitu sebesar $179,9{ }^{\circ} \mathrm{C}$, maka panas brine tersebut dapat dimanfaatkan kembali untuk memanaskan $\mathrm{i}-\mathrm{C}_{5} \mathrm{H}_{12}$ pada binary cycle yang kedua seperti pada gambar 3. Dari hasil simulasi yang telah dilakukan di Aspen HYSIS pada tabel 2 didapatkan turbin K-100-1 menghasilkan daya sebesar $4.236 \mathrm{~kW}$, sedangkan pompa membutuhkan daya sebesar $226,7 \mathrm{~kW}$. Oleh karena itu, sistem binary cycle loop pertama menghasilkan daya listrik bersih sebesar 2.205,12 kW. Sedangkan didapatkan turbin K-100-2 menghasilkan daya sebesar $4.079 \mathrm{~kW}$, sedangkan pompa membutuhkan daya sebesar $88,05 \mathrm{~kW}$. Oleh karena itu, sistem binary cycle loop kedua menghasilkan daya listrik bersih sebesar 2.195,023 kW. Sehingga kombinasi teknologi single flash steam dengan dual binary cycle ini menghasilkan daya sebesar 18.329,77 kW dengan efisiensi overall plant (hukum kedua temodinmika) sebesar 30,81\%. Sedangkan efisiensi carnot cycle untuk sistem kombinasi single flash dan dual binary cycle sebesar 33,35\%, dengan suhu brine keluaran dari preheater sebesar $49,1^{\circ} \mathrm{C}$. Hal tersebut menunjukkan terjadi peningkatan daya sebesar 31,59 $\%$ dari single flash steam. Hal tersebut sesuai dengan literatur yang menunjukkan bahwa akan 
meningkatkan efisiensi lebih dari 20\%. Namun, teknologi ini tidak dijadikan rujukan dalam pemilihan teknologi proses geothermal karena efisiensinya lebih kecil dibandingkan dari kombinasi single flash dengan binary cycle.

Tabel 2. Hasil Simulasi PLTP Teknologi Dual Binary Cycle pada Kombinasi Single Flash dan Dual Binary cycle dengan Aspen HYSIS

\begin{tabular}{|c|c|c|c|}
\hline Arus & $\mathbf{P}(\mathbf{k P a})$ & $\mathbf{T}(\mathbf{K})$ & $\begin{array}{c}\text { Laju Massa } \\
(\mathbf{k g} / \mathbf{s})\end{array}$ \\
\hline 3 & 1000 & 453,15 & 340.920 \\
\hline $7 \mathrm{a}$ & 1000 & 444,05 & 340.920 \\
\hline 7 & 1000 & 390,85 & 340.920 \\
\hline $7 \mathrm{~b}$ & 1000 & 372,36 & 340.920 \\
\hline 8 & 1000 & 322,25 & 340.920 \\
\hline $\mathrm{a}$ & 2000 & 427,15 & 200.000 \\
\hline $\mathrm{b}$ & 186,6 & 365,55 & 200.000 \\
\hline $\mathrm{d}$ & 186,6 & 320 & 200.000 \\
\hline $\mathrm{e}$ & 2000 & 321,28 & 200.000 \\
\hline $\mathrm{f}$ & 2000 & 427,55 & 200.000 \\
\hline $\mathrm{g}$ & 686,9 & 371,24 & 250.000 \\
\hline $\mathrm{h}$ & 104,7 & 331,41 & 250.000 \\
\hline $\mathrm{i}$ & 104,7 & 301,95 & 250.000 \\
\hline $\mathrm{j}$ & 686,9 & 302,33 & 250.000 \\
\hline $\mathrm{k}$ & 686,9 & 371,24 & 250.000 \\
\hline
\end{tabular}

Pada gambar 4 dibawah menunjukkan dalam Aspen HYSIS telah dibuat skema PLTP dengan teknologi dual binary cycle dengan kondisi operasi masing-masing pada setiap arus. Geofluida masuk sebagai pemanas pada Evaporator (E-100) binary cycle loop pertama yang akan memanaskan isopentane sebagai working fluida menjadi vapor untuk diekspansi dalam turbin (K100) dengan menghasilkan kerja. Dalam siklus ini memerlukan pompa (P-100) yang akan mengirimkan isopentane fasa cair dari cooler (E-101) menuju preheater (E-102) untuk dipanaskan kembali. Geofluida loop binary pertama akan masuk sebagai pemanas pada Evaporator (E-100-2) yang akan memanaskan isopentane sebagai working fluida menjadi vapor untuk diekspansi dalam turbin (K-100-2) dengan menghasilkan kerja.. Banyaknya massa isopentane sebagai working fluida pada loop pertama dan kedua juga sebanyak $200.000 \mathrm{~kg} / \mathrm{jam}(55,56 \mathrm{~kg} / \mathrm{s})$ dan $250.000 \mathrm{~kg} / \mathrm{jam}$ $(69,44 \mathrm{~kg} / \mathrm{s})$. 


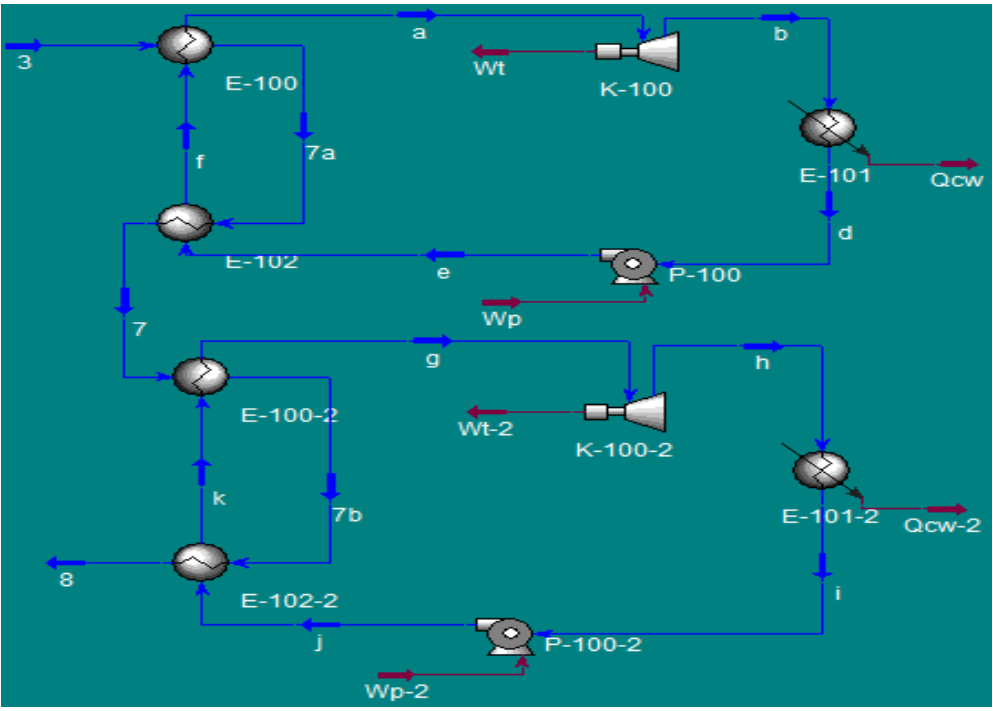

Gambar 4 Skema Skema PLTP dengan teknologi Dual Binary Cycle pada kombinasi Single Flash dan Dual Binary cycle

Tabel 3 Perbandingan Daya Listrik ( $\mathrm{W}_{\text {nett }}$ ) dan Efisiensi pada masing-masing Teknologi Pembangkit Listrik Tenaga Panas Bumi

\begin{tabular}{|c|c|c|c|c|}
\hline Parameter & $\begin{array}{c}\text { Single } \\
\text { Flash }\end{array}$ & $\begin{array}{c}\text { Double } \\
\text { Flash }\end{array}$ & $\begin{array}{c}\text { Combine Binary } \\
\text { Cycle }\end{array}$ & $\begin{array}{c}\text { Dual Binary } \\
\text { Cycle }\end{array}$ \\
\hline $\mathrm{W}_{\mathrm{nett}}(\mathrm{kWe})$ & $13.929,63$ & $16.558,26$ & $18.456,24$ & $18.329,77$ \\
\hline$\%$ & 23,41 & 27,83 & 31,02 & 30,81 \\
\hline
\end{tabular}

Dengan melakukan pemodelan sebanyak 3 macam teknologi yaitu single flash, double flash, dan kombinasi dengan binary cycle. Didapatkan daya listrik yang dihasilkan terbesar pada kombinasi teknologi single flash steam dengan binary cycle. Hal tersebut didukung dengan tingginya pula efisiensi hukum kedua termodinamika dibandingkan dengan macam teknologi yang diusulkan pada pembangkit listrik tenaga panas bumi Geo Dipa unit Dieng, Jawa Tengah.

\section{KESIMPULAN}

Penelitian ini telah menginvestigasi peningkatan efisiensi untuk teknologi pembangkit listrik tenaga panas bumi dengan proses single flash steam di Dieng dengan memodifikasi sistem double flash steam berdasarkan pengembangan model matematis berprinsip hukum termodinamika. Perhitungan dilakukan dengan menggunakan software Engineering Equation Solver (EES).

Kombinasi teknologi single flash steam dan binary cycle ini menghasilkan daya sebesar 18.456,24 kW dengan efisiensi overall plant sebesar 31,02\%. Hal tersebut memiliki efisiensi terbesar sehingga dirujuk sebagai pilihan teknologi proses geothermal yang tepat untuk PLTP PT. Geo Dipa Energi unit Dieng, Jawa Tengah. Sedangkan teknologi kombinasi single flash dengan dual binary cycle ini menghasilkan daya sebesar $18.329,768 \mathrm{~kW}$ dengan efisiensi overall plant sebesar $30,81 \%$.

Modifikasi teknologi proses disertai kombinasi dengan flash steam terus diupayakan. Kendala yang terjadi pada lapangan yaitu pada sistem pengendapan impuritis untuk mencegah pembentukan silika pada tiap-tiap komponen menjadi masalah besar. Selain itu, brine keluaran dari separator bertekanan tinggi memiliki karakteristik mudah menjadi kondensat. Sehingga dengan demikian, biaya produksi yang dikeluarkanpun juga semakin besar.

\section{DAFTAR PUSTAKA}


[1] Bertani, Ruggero. 2010. "Geothermal power generation in the world 2005-2010 update report". Journal of Geothermic 41. 1-29.

[2] Kanoglu M. 2002. "Energy Analysis of a dual level binary geothermal power plant"; Journal of Geothermic 31, 709-724.

[3] Zarrouk, S.J. 2014. "Efficiency of geothermal power plants: A worldwide review”. In: Lecture. University of Auckland.

[4] Dickson, M.H., Fanelli, M. 2003. "Geothermal Energy: Utilization and Technology" Routledge, ISBN-10:1844071847, IBN-13: 978-1844071845.

[5] Zuchrillah, Daril Ridho, Handogo, Renanto, Juwari. 2016. "Optimisasi Teknologi Proses Geothermal Sistem Flash Steam pada Pembangkit Listrik Tenaga Panas Bumi di Indonesia". Prosiding SENIATI ITN MALANG vol 1.

[6] Hudson, R.B.1988. "Technical and economic overview of geothermal atmospheric exhaust and condensing turbines binary cycles and biphasic plant". Geothermics 17, 51-74.

[7] Jorgensen SE, Mejer H. 1977. "Ecological buffer capacity. Ecol Model”,3:39-45.47,49,51,5361.

[8] Sugiyono, Agus, 2000. "Studi Pendahuluan untuk Analisis Energi-Eksergi Kota Jakarta", Direktorat Teknologi Konversi dan Konversi Energi, BPPT, Jakarta.

[9] Pambudi, NA, Itoi R, Jalilinasrabady S, Khasani J. 2014. "Exergi analysis and optimization of Dieng single-flash geothermal power plant", Energy Convers Manag; 78;405-11.

[10] Michaelides, Efstathios E. dan Scott, Gregory J. 1984. "A Binary-Flashing Geothermal Power Plant"; Energy vol 9, No. 4, pp. 323-331. 